\title{
Species jump may be responsible for seals' virus infection
}

\section{London}

THE virus that has killed several thousand common (or harbour) seals from the Baltic and North Seas during the past six months (see Nature 334, 553; 1988) is indistinguishable from canine distemper virus (CDV) the cause of the common infection of household pets and working dogs.

This astonishing finding is described in this week's Nature (Scientific Correspondence, page 20) by Dr Albert Osterhaus of the National Institute of Public Health and Environmental Protection in the Netherlands, and Dr Lies Vedder of the Pieterburen Seal Orphanage. The discovery raises the possibility that the virus has been transferred from dogs to seals in the recent past, although further investigations will be needed to prove that point.

Already there is evidence that the virus has spread from common seals to grey seals, and the Dutch finding is bound to raise concern for sea mammals other than seals, including dolphins and whales. At present there is no evidence that other sea mammals have been infected; but if the transfer of CDV to seals proves to have been recent, there may not yet have been time for that to have happened. Though the virus is not yet proven to be CDV, it is a very similar member of the same family of viruses, known as morbilliviruses, which includes those responsible for human measles and and rhinderpest in cattle, as well as a similar disease in goats.

An urgent programme to make a vaccine against the seal virus is now under way. The Dutch group has made about 100 doses of a possible vaccine that will be administered to seals in orphanages and sanctuaries in The Netherlands and Scandinavia this week, to tell whether the preparation offers protection to uninfected seals. But attempts, at the end of last week, to arrange for the production of materials for a vaccine in larger quantities through Coopers, the veterinary subsidiary of the Wellcome Foundation, have not yet materialized.

Osterhaus stresses that the usefulness of a vaccine may be limited. Even if the vaccine does prevent infection, there will be formidable problems in using it to protect wild animals. Why not use the vaccine against CDV which have been used to protect dogs? Osterhaus believes it would be wrong to use it in seals because of the risks of using a live-virus vaccine in a population of wild animals.

The Dutch claim that a CDV-like virus is responsible for the seal deaths of 1988 will surprise many virologists. Dr Cambell Cornwell at the Veterinary School at Glasgow, who is an expert on CDV, says that the reports, "if true, are sensational".
How a virus such as CDV can go "from dogs to pinnipeds makes the mind boggle". He says it will take some time to convince all researchers that $\mathrm{CDV}$ is the cause of the seal epidemic.

But the Dutch researchers believe there is evidence other than the properties of the virus to suggest that CDV has transferred from dogs to seals.

Dr Dernt Klingeborn, a virologist at the Uppsala centre, says that, this season, harp seals in Greenland waters migrated unusually far south, towards the coast of Denmark. He links this with an outbreak of CDV infection that wiped out 1,000 sleigh dogs in the very North of Greenland earlier this year, saying, "this is a very interesting coincidence".

Klingeborn believes the harp seals may have carried the virus to infect common seals in the North Sea and the Baltic, and now plans to check them for antibodies against the virus. He also says that the dogs in Greenland may have caught distemper by eating infected seal-meat. But Hans Jacob Helms of the Greenland administration believes the outbreak of distemper was imported from Canada either by fox or ravens, known carriers of CDV which also infects bears and wolves.

The effect of this year's epidemic on the future of the seal population is not yet clear. Osterhaus believes that this year's "wave of infection" will eventually "work itself out" as seals either become immune or succumb, but that "it'll probably come back", possibly doing less damage because some seals will then be immune.

Looking back on the false trails of the herpes and picornaviruses that misled him and his colleagues, Osterhaus says he now believes that these infections are consequences, not causes, of the seal disease.

There are no indications that people are susceptible to the seal version of the CDV virus. The researchers in close contact with infected seals say tests on themselves have all proved negative. Nor is there a danger that the seals have been infected by human measles virus, which has been eliminated as a cause in the course of the Dutch research.

Although the new research shows no direct link between seal disease and pollution, the possibility remains that pollution may play an important part in making seals more susceptible to infection and also by hampering the recovery of the seal population from this year's epidemic.

In collaboration with researchers in Britain, Osterhaus hopes to embark immediately on a $£ 150,000$ programme, with funds from the European Commission, to investigate links between pollution and the seal disease. Christine McGourty
Shuttle in September

\section{Washington}

THE launch date for the US space shuttle Discovery is now expected to be the last week of September, but National Aeronautics and Space Administration (NASA) officials are not prepared to set a precise date until a flight readiness review scheduled for 13 and 14 September, has been completed.

Meanwhile NASA and law enforcement officials have been investigating an apparent case of sabotage at the Hydra Pak plant in Utah where the shuttle's solid rocket booster $\mathrm{O}$-rings are manufactured. Inspections revealed that several of the $\mathrm{O}$-rings had been slashed with a razor or similar instrument, but NASA says that none of the damaged $\mathrm{O}$-rings ever left the manufacturers plant.

J.P.

\section{Material objections \\ London}

THE restructuring of the Science and Engineering Council (SERC) now under way resulted last month in the formation of a new Materials Commission which absorbs among other things a significant part of the responsibilities of the subcommittee for inorganic chemistry. Now researchers in chemistry are worried that inorganic chemistry might cease to exist as a separate and identifiable entity. In a letter last week to the head of SERC, Professor Bill Mitchell, 10 professors of chemistry, led by Professor Peter Maitlis of the University of Sheffield, criticize a rumoured move in this direction and request denial that such a move is being considered. Without issuing a straight denial, Mitchell says he will "try to ensure" that inorganic chemistry does not lose its identity. He says that absorption of the committee's responsibilities by the commission was a recognition of the subject's importance, and that funding for those areas taken over may increase. C.McG.

\section{HERA here}

\section{Munich}

THE $30 \mathrm{GeV}$ electron ring of the HERA electron-proton collider at DESY (Deutsches Elektronen-Synchrotron), Hamburg, West Germany, was successfully run with its first electrons on 20 August. The test of the electron ring, at 7 $\mathrm{GeV}$, showed that the pre-accelerator and central control facilities were working well.

Superconducting magnets for the PETRA ring where protons will be accelerated to $40 \mathrm{GeV}$ before injection into the collider will be installed this autumn. Both rings will be ready for the first experiments in mid-1990.

HERA (Hadron Electron Ring Anlage) will be the world's first high-energy electron-proton collider. The ring, which is 6,336 metres long, will cost an estimated $\$ 500$ million. 